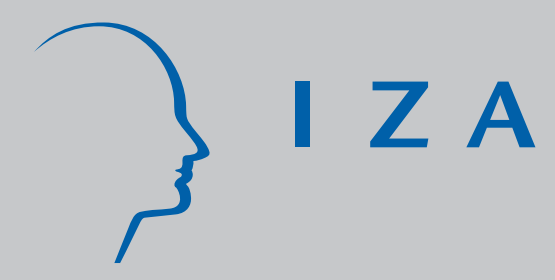

IZA DP No. 3023

The Expansion of Higher Education and Time-Consistent Taxation

Panu Poutvaara

September 2007 


\title{
The Expansion of Higher Education and Time-Consistent Taxation
}

\author{
Panu Poutvaara \\ University of Helsinki \\ and IZA
}

Discussion Paper No. 3023

September 2007

\author{
IZA \\ P.O. Box 7240 \\ 53072 Bonn \\ Germany \\ Phone: +49-228-3894-0 \\ Fax: +49-228-3894-180 \\ E-mail: iza@iza.org
}

\begin{abstract}
Any opinions expressed here are those of the author(s) and not those of the institute. Research disseminated by IZA may include views on policy, but the institute itself takes no institutional policy positions.

The Institute for the Study of Labor (IZA) in Bonn is a local and virtual international research center and a place of communication between science, politics and business. IZA is an independent nonprofit company supported by Deutsche Post World Net. The center is associated with the University of Bonn and offers a stimulating research environment through its research networks, research support, and visitors and doctoral programs. IZA engages in (i) original and internationally competitive research in all fields of labor economics, (ii) development of policy concepts, and (iii) dissemination of research results and concepts to the interested public.
\end{abstract}

IZA Discussion Papers often represent preliminary work and are circulated to encourage discussion. Citation of such a paper should account for its provisional character. A revised version may be available directly from the author. 
IZA Discussion Paper No. 3023

September 2007

\section{ABSTRACT}

\section{The Expansion of Higher Education and Time-Consistent Taxation}

This paper analyzes educational choices and political support for subsidies to higher education in the presence of a time-consistency problem in income redistribution. There may be political support for so generous subsidization that it motivates the median voter to obtain higher education. As a result of increasing own income, the median voter prefers in the future lower taxes than without higher education. Therefore, the expansion of participation in higher education during the second half of the 20th century may have partly been driven by the aim to limit the political support for overly generous income redistribution.

JEL Classification: H52, I22, D72

Keywords: education, time-consistency problem, voting, subsidies to education

Corresponding author:

Panu Poutvaara

Department of Economics

University of Helsinki

P.O. Box 17 (Arkadiankatu 7)

00014 Helsinki

Finland

E-mail: panu.poutvaara@helsinki.fi 


\section{Introduction}

The second half of the 20th century saw an unprecedented expansion of participation in higher education around the world. Between 1960 and 2000, the number of tertiary students per capita increased seven-fold in 15 industrialized Western countries. In Western democracies, it is nowadays common that more than half of the younger cohorts obtain higher education. (Schofer and Meyer, 2005) The expansion of the participation in higher education coincided with a significant increase in the GDP share of the tax burden after the Second World War. Income transfers increased much more than public sector consumption. However, the trend towards higher taxes and income redistribution was reversed in most countries in the 1980s and 1990s. Most notably, President Reagan and Prime Minister Thatcher made reducing tax burden and income redistribution a central part of their policies.

This paper explores the connection between income redistribution and the expansion of higher education. The starting point of the analysis is the time-consistency problem in income redistribution, due to political decision-making in the future. After investments in education have taken place, the median voter has an incentive to impose high taxes. The paper identifies a strategic policy to counteract the incentive to impose high taxes in the future: generous subsidies to higher education may encourage the median voter to obtain higher education. As a result of increasing own income, the median voter prefers in the future lower taxes than without university education.

Also Konrad (1995) and Boadway, Marceau and Marchand (1996) have suggested that governments may subsidize education due to time-consistency problem. Two features distinguish this paper. First, Konrad (1995) and Boadway, Marceau and Marchand (1996) have analyzed optimal subsidies with given government preferences. This paper endogenizes government preferences through a median voter model, taking into account that also the productivity of the median voter is endogenous. Second, this paper identifies a possibility that subsidies are used not only to avoid a downward distortion in investment in higher education, but may actually be used to create an upward distortion. The motivation for such an upward distortion resides in alleviating the time-consistency problem of excessive redistribution by increasing the future income of the median voter.

In a seminal contribution, Meltzer and Richard (1981) showed that a Downsian median voter model can explain the increase in the size of the public sector in the 19th and 20th century. Their explanation is that the spread of the franchise increased the number of voters with relatively low incomes, shifting the position of the decisive voter down the distribution of income. So, tax rates rose. Meltzer and Richard (1981) analyzed voting with given productivities. This paper endogenizes productivities and shows that the median voter model could explain also the historical expansion in the participation in higher education, in the presence of time-consistency problem.

The insight given is related to the general idea that current policies can be used to influence future policies. Glazer (1989) analyzes the choice of durability in public capital projects. He shows that uncertainty about future voting outcomes generates a bias toward overinvesting in long run projects. Tabellini and Alesina (1990) find that if there is disagreement on optimal composition of public spending between current and future majorities, the current 
majority may strategically favor a public deficit. This paper finds that all voters may agree on public expenditures in the first period to change the future incentives of the median voter in the second, even when the identity of the median voter does not change. Finally, Hassler et al. (2003) analyze Markov perfect equilibria in repeated voting on distorting income redistribution when citizens invest in their education. They find multiple equilibria: In some equilibria redistribution persists forever, while in others, even a majority of beneficiaries vote strategically so as to induce the end of the welfare state next period. This paper suggests, instead, that subsidies to education could be used to limit redistribution relative to GDP, at the same time increasing total production sufficiently so that the absolute level of transfers increase.

The rest of the paper is organized as follows. Section II presents the model and analyzes educational choices and voting on income redistribution in the absence of subsidies to education. Section III shows the main result: with income redistribution, all voters may agree on subsidies that result in larger investments in higher education than in a laissez-faire economy. Section IV discusses the effects of the mobility of labor and complementarities in production, and Section V concludes.

\section{The Model}

The economy lasts for two periods. There are two types of education, labelled vocational education and university education. In the first period, young individuals decide which education to obtain. In the second period, the production of a single consumption good takes place. The production function is linear in the efficiency units of labor. There exists a storage technology to move resources over time at a given rate of return, normalized to zero. For example, in a small open economy the storage technology may take the form of international capital markets. For simplicity, all consumption takes place in the second period and utility is linear in consumption. The government collects taxes to redistribute income in the second period. The length of the second period is one. The length of the first period corresponds to the duration of either education.

The productivity in case of receiving university education is denoted by variable $h$, labelled ability for simplicity. The individual-specific ability variable follows a continuous distribution in an interval, $h \in[0, \bar{h}]$. The density function of $h$ is $f(h)$ and its cumulative distribution function is $F(h)$. The total population size is normalized to unity. A citizen who obtains vocational education has productivity $v$, independently of ability. The cost of university education is $c$, while the cost of vocational education is normalized to zero. We denote the wage rate of individual $i$ by $w_{i}$, so that $w_{i}=v$ for those with vocational education and $w_{i}=h_{i}$ for those with university education. The ability threshold at and above which citizens choose higher education is denoted by $\widetilde{h}$. The median ability is denoted by $h_{m}$.

The government taxes income above an exemption of tax-free income $e$ by a constant marginal tax rate $\tau, 0 \leq \tau \leq 1$. Tax revenues are used to finance a uniform lump-sum transfer $b$. Therefore, the tax and transfer policy is a triple $(e, \tau, b)$. Both the marginal tax rate and the exemption are decided by the median voter at the beginning of the second period, and the lump-sum transfer is then determined residually from the government budget 
constraint. The efficiency costs of taxation are captured by assuming that a fraction $\delta \tau$ of the tax revenue that the government could collect without distortions is lost. The value of $\delta$ reflects, for example, various administrative costs and the distortions in economic activity that are caused by the tax wedge. The multiplicative form $\delta \tau$ captures the idea that the distortions are increasing in the marginal tax rate. If $\delta$ were zero, taxation would not cause any distortions. When $\delta>0$, the tax revenue is maximized by the tax rate $\min \left(\frac{1}{2 \delta}, 1\right)$. To rule out 100 percent marginal tax, we assume that $\delta>0.5$. The government's (second-period) budget constraint is

$$
b=\tau(1-\delta \tau) \int_{h=0}^{\bar{h}} f(h) \max (0, w(h)-e) d h,
$$

where $w(h)=v$ for those with vocational education and $w(h)=h$ for those with university education. The presence of free disposable income is a simple way to capture the possibility of progressive taxation. It allows the median voter model to replicate the stylized fact that in most Western countries, the average tax rates increase in income level, even when not taking into account the effects of income transfers.

Citizens have a double role in the economy. As workers, they choose in the first period whether to obtain vocational education or university education, taking the expected marginal wage tax rate, the expected exemption of tax-free income, and the expected lump-sum transfer as given. As voters, they vote on the exemption and on the marginal wage tax rate above it in the second period, taking into account how the lump-sum transfer is determined by the government budget constraint (1).

We solve the equilibrium by backwards induction. In the second period, educational choices have already been made. The lifetime income as a function of the tax parameters $\tau$, $e$ and $b$ and the individual-specific ability $h_{i}$ is

$$
V_{i}^{v}\left(\tau, e, b, h_{i}\right)=\min (e, v)+(1-\tau) \max (0, v-e)+b
$$

if citizen $i$ chose vocational education in the first period, and

$$
V_{i}^{u}\left(\tau, e, b, h_{i}\right)=\min \left(e, h_{i}\right)+(1-\tau) \max \left(0, h_{i}-e\right)+b-c
$$

if citizen $i$ chose university education in the first period. In both (2) and (3), the first term on the right-hand side reports the tax-exempt earnings, and the second term the aboveexemption after-tax income, if any. The third term is the uniform lump-sum transfer that citizens take as given when deciding on their education. When voting in the second period, citizens take into account that $b$ is determined by (1). Finally, the last term on the right-hand side of (3) captures the cost of university education. Setting $\tau=e=b=0$, we can solve from (2) and (3) the laissez-faire cutoff level above which university education is chosen, as benchmark for future comparisons:

$$
\widetilde{h}^{L F}=v+c .
$$


Political decisions are made by direct democracy at the beginning of the second period. Citizens vote first on the exemption, and then on the marginal wage tax rate, collected above the exemption. The assumed timing is without loss of generality. The results would not change if we would assume the opposite timing or simultaneous voting as there is a unique median voter who is the same in both dimensions. With simultaneous voting, we would solve for a structure-induced equilibrium, see Shepsle (1979). We denote the equilibrium values by a hat, so that $\widehat{\tau}(\widetilde{h})$ and $\widehat{e}(\widetilde{h})$ give the political equilibrium marginal wage tax rate and tax exemption, as a function of the educational choices that are summarized by $\widetilde{h}$. The political equilibria can be summarized as follows:

Lemma 1 If $h_{m}<\widetilde{h}, \widehat{e}=v$ and $\widehat{\tau}=\frac{1}{2 \delta}$. If $h_{m} \geq \widetilde{h}, \widehat{e}=h_{m}$ and $\widehat{\tau}=\frac{1}{2 \delta}$.

Proof. (i) Assume first that $h_{m}<\widetilde{h}$, so that the median voter has vocational education. For any $\tau>0, V_{i}^{v}$ as defined in (2) (inserting (1)) is maximized by choosing $e=v$. Assume next that $h_{m} \geq \widetilde{h}$, so that the median voter has university education. For any $\tau>0, V_{i}^{u}$ as defined in (3) (inserting (1)) is maximized by choosing $e=h_{m}$. This establishes that the median voter chooses $e$ equal to his or her own income, independently of the marginal tax rate collected on income above it. (ii) Taking into account that $e$ equals the median voter's income, the marginal wage tax rate enters (2) (or (3)) only through its effect on $b$. By (1) and taking into account the restriction that $\delta>0.5$, this is maximized by $\widehat{\tau}=\frac{1}{2 \delta}$.

By Lemma 1, the median voter chooses the tax exemption to equal his or her own income, and then the marginal tax rate to maximize the tax revenue from any income above that. We next define the tentative equilibria in the case in which the median voter has obtained vocational education (labelled Vocational Equilibrium), and in case the median voter has obtained university education (labelled University Equilibrium):

Definition 1 Vocational Equilibrium is characterized by: $\widetilde{h}=v+\frac{c}{1-\frac{1}{2 \delta}}>h_{m}, \widehat{e}=v$, $\widehat{\tau}=\frac{1}{2 \delta}, b=\frac{1}{4 \delta} \int_{h=v+\frac{c}{1-\frac{1}{2 \delta}}}^{\bar{h}} f(h)(h-v) d h$.

Definition 2 University Equilibrium is characterized by: $\widetilde{h}=v+c \leq h_{m}, \widehat{e}=h_{m}$, $\widehat{\tau}=\frac{1}{2 \delta}, b=\frac{1}{4 \delta} \int_{h=h_{m}}^{\bar{h}} f(h)(h-v) d h$.

There are no other possible equilibria. The median voter has either vocational education or university education, and this then determines $\widehat{e}$ and $\widehat{\tau}$, which in turn determine a unique value for $\widetilde{h}$ by (2) and (3) in either equilibrium. Comparisons with (4) reveal that the possibility of redistribution does not change educational choices compared with laissez-faire outcome in the University Equilibrium. In the Vocational Equilibrium, a smaller fraction of population chooses university education than in the laissez-faire solution. We find:

Proposition 1 (i) If $h_{m}<v+c$, the only subgame-perfect equilibrium is the Vocational Equilibrium. 
(ii) If $h_{m}>v+\frac{c}{1-\frac{1}{2 \delta}}$, the only subgame-perfect equilibrium is the University Equilibrium. (iii) If $v+c \leq h_{m} \leq v+\frac{c}{1-\frac{1}{2 \delta}}$, both the Vocational Equilibrium and the University Equilibrium are subgame-perfect equilibria.

Proof. In a tentative Vocational (University) Equilibrium, we insert $\widehat{e}$ and $\widehat{\tau}$ from Definition 1 (Definition 2) into (2) and (3) with $h_{i}=h_{m}$ to verify whether it is individually optimal for the median voter to make the postulated educational choice in the first period. When doing this, $b$ is taken to be the same in the two equations as citizens take the lumpsum transfer as given when making their individual educational choice. (i) If $h_{m}<v+c$, the majority of citizens always chooses vocational education. The Vocational Equilibrium follows by Lemma 1. $b$ given in Definition 1 is found by inserting the parameter values into (1). (ii) If $h_{m}>v+\frac{c}{1-\frac{1}{2 \delta}}$, the Vocational Equilibrium is not subgame-perfect as by (2) and (3), the median voter would rather deviate in the first period and obtain university education. The University Equilibrium turns out to be subgame-perfect. $b$ given in Definition 2 is found by inserting the parameter values into (1). (iii) Inserting $\widehat{\tau}=\frac{1}{2 \delta}, \widehat{e}=v$ and $h_{i}=h_{m}$ into (2) and (3) and comparing, we see that $V_{m}^{v}\left(\frac{1}{2 \delta}, v, b, h_{m}\right)>V_{m}^{u}\left(\frac{1}{2 \delta}, v, b, h_{m}\right)$ for all $b$. Inserting $\widehat{\tau}=\frac{1}{2 \delta}, \widehat{e}=h_{m}$ and $h_{i}=h_{m}$ into (2) and (3) and comparing, we see that $V_{m}^{u}\left(\frac{1}{2 \delta}, h_{m}, b, h_{m}\right)>V_{m}^{v}\left(\tau, h_{m}, b, h_{m}\right)$ for all $b$. Thus, both equilibria are subgame-perfect.

Proposition 1 shows that if the median voter's productivity with university education does not exceed his or her productivity with vocational education at least by the cost of university education, the only subgame-perfect equilibrium is such that the median voter chooses vocational education. If, on the other hand, the median voter's productivity with university education is sufficiently higher than his or her productivity with vocational education and the marginal wage tax rate is not too high, then the only subgame-perfect equilibrium is such that the median voter chooses university education. When the median voter's productivity in case of obtaining university education falls between these bounds and the marginal wage tax rate is sufficiently low, there are two subgame-perfect equilibria. Which one is selected could then depend on expectations.

\section{Redistribution and Subsidies to Education}

We now introduce the possibility of subsidies to education. Instead of analyzing just whether subsidies to education could find majority support in voting, we ask whether subsidies to education could receive unanimous support. How the results would differ with voting is discussed at the end of this section.

Still, there may be several subsidy levels that could find unanimous support when the alternative is no subsidies, with different ability types preferring different subsidy levels. We focus on the subsidies to higher education that would be preferred by low-ability citizens, who choose vocational education.

Subsidies to education need to be financed. In the framework of this paper, labor supply takes place only in the second period. Thus, it is assumed that the government borrows in the first period from abroad to finance subsidies to university education, if any, repaying its debt in the second period. The subsidy is denoted by $s, s \geq 0$. The subsidy is paid 
to everyone who obtains university education. The government's (second-period) budget constraint is

$$
b=\tau(1-\delta \tau) \int_{h=0}^{\bar{h}} f(h) \max (0, w(e)-e) d h-s(1-F(\widetilde{h})) .
$$

By (5), subsidies to university education are financed from the same tax revenue as transfers. Thus, also low-ability citizens participate in subsidizing university education. This may be optimal from their perspective, as they also share part of the returns to university education through second-period income redistribution. As subsidies are effectively financed from lump-sum transfers, those who obtain university education always are in favor of any subsidies that those who obtain vocational education are willing to accept. Therefore, we focus from now on only on whether low-ability citizens favor subsidies. We solve the equilibrium with subsidies to university education by backwards induction. In the second period, educational choices have already been made. The lifetime income as a function of tax parameters $\tau, e$ and $b$, subsidy parameter $s$ and the individual-specific ability $h_{i}$ is

$$
V_{i}^{v s}\left(\tau, e, b, s, h_{i}\right)=\min (e, v)+(1-\tau) \max (0, v-e)+b
$$

if citizen $i$ chose vocational education in the first period, and

$$
V_{i}^{u s}\left(\tau, e, b, s, h_{i}\right)=\min \left(e, h_{i}\right)+(1-\tau) \max \left(0, h_{i}-e\right)+b-c+s
$$

if citizen $i$ chose university education in the first period. In both (6) and (7), the first term on the right-hand side reports the tax-exempt earnings, and the second term the aboveexemption after-tax income, if any. The third term is the uniform lump-sum transfer that citizens take as given when deciding on their education. When voting in the second period, citizens take into account that $b$ is determined by (5). Finally, the last two terms on the right-hand side of (7) capture the cost of university education, net of subsidies. We find:

Lemma 2 With any subsidies, it holds that if $h_{m}<\widetilde{h}, \widehat{e}=v$ and $\widehat{\tau}=\frac{1}{2 \delta}$, and if $h_{m} \geq \widetilde{h}$, $\widehat{e}=h_{m}$ and $\widehat{\tau}=\frac{1}{2 \delta}$.

Proof. Follows as in the proof for Lemma 1, replacing $V_{i}^{v}$ by $V_{i}^{v s}, V_{i}^{u}$ by $V_{i}^{u s}$, (2) by (6), (3) by (7), and (1) by (5).

To avoid the complications of equilibrium selection with multiple equilibria, we assume that either $h^{m}<v+c$ or $h^{m}>v+\frac{c}{1-\frac{1}{2 \delta}}$. This implies that with $s=0$, the economy is for sure either in the Vocational Equilibrium or in the University Equilibrium. In the area $v+c \leq h^{m} \leq v+\frac{c}{1-\frac{1}{2 \delta}}$ there would be two alternative subgame-perfect equilibria without subsidies. If subsidies could help to coordinate to select the University Equilibrium, this would be an additional argument in favor of introducing subsidies. We first establish:

Proposition 2 If $h_{m}>v+\frac{c}{1-\frac{1}{2 \delta}}$, there is no unanimous support for introducing any subsidies. 
Proof. If $h_{m}>v+\frac{c}{1-\frac{1}{2 \delta}}$, the University Equilibrium prevails with zero subsidies. By Lemma $1, \widehat{e}=h_{m}$. If there would be subsidies to university education, this would lower $\widetilde{h}$. However, as $h_{m}=\widehat{e}$ by Lemma 2 also with subsidies, those who would obtain education after subsidies are introduced, but not without subsidies, would have less than tax-exempt income. By (5), any positive subsidies reduce $b$ and, thus, by (6), lower the utility of those who obtain vocational education.

By Proposition 2, there is no support for subsidies to university education from the lowability citizens if the majority of population would choose university education also without subsidies. Importantly, subsidies to university education may receive unanimous political support when the subsidies are so generous that the median voter who would not choose university education without subsidies chooses university education with subsidies:

Proposition 3 If $h_{m}<v+c$, a subsidy at rate $s^{U E}=v-h_{m}+c$ would generate a Paretoimprovement, provided that

$$
\begin{aligned}
& \frac{1}{4 \delta} \int_{\frac{h_{i}}{1-h_{m}}}^{v+\frac{c}{2 \delta}} f(h)\left(h-h_{m}\right) d h \\
- & \frac{1}{4 \delta} \int_{h_{i}=v+\frac{c}{1-\frac{1}{2 \delta}}}^{h} f(h)\left(h_{m}-v\right) d h>0 \\
& -\left(v-h^{m}+c\right)\left(1-F\left(h_{m}\right)\right)
\end{aligned}
$$

and that if both the University Equilibrium and the Vocational Equilibrium are subgameperfect equilibria with subsidies, the University Equilibrium prevails. Furthermore, citizens who obtain vocational education strictly prefer $s^{U E}$ to any higher subsidy.

Proof. Proof is given in the Appendix.

While the inequality (8) may appear quite complicated, each term has a clear economic interpretation. The term on the first line on the left-hand side reports the tax revenue that could be collected from those who would choose vocational education in the absence of subsidies, and switch to university education with subsidies. Here, $\widehat{e}=h_{m}$ and $\widehat{\tau}=\frac{1}{2 \delta}$ are already inserted. The term on the second line reports the lost tax revenue from those who would have chosen university education even without subsidies. This loss occurs as when the median voter switches from vocational education to university education, the exemption increases from $v$ to $h_{m}$. Finally, the term on the third line is the cost of subsidies at rate $s^{U E}=v-h_{m}+c$, multiplied the number of those who choose university education, $\left(1-F\left(h_{m}\right)\right)$. Therefore, subsidies win universal support if they increase the total tax revenue more than they cost.

Proposition 3 establishes that the presence of income redistribution may explain an otherwise puzzlingly large expansion of higher education. With the subsidy rate $s^{U E}, \widetilde{h}=h_{m}$. Comparing this with (4) and taking into account that $h_{m}<v+c$ when the Proposition 3 applies, we see that the subsidies at the rate $s^{U E}$ result in a larger fraction of population choosing university education than in the laissez-faire outcome. However, it is not necessarily optimal to choose so generous subsidies that the University Equilibrium is reached, even when $h_{m}<v+c$ : 
Proposition 4 (i) If $h_{m}<v+c$ and the subsidies are restricted to the interval $0 \leq s<$ $v-h_{m}+c$, the optimal subsidy from the perspective of low-ability citizens is given by

$$
s^{V E}=\arg \max _{s \in\left[0, v-h_{m}+c\right)}\left[\frac{1}{4 \delta} \int_{h=v+\frac{c-s}{1-\frac{1}{2 \delta}}}^{\bar{h}} f(h)(h-v) d h-\left(1-F\left(v+\frac{c-s}{1-\frac{1}{2 \delta}}\right)\right) s\right] .
$$

(ii) If any non-negative subsidies are allowed, the low-ability citizens prefer either $s^{V E}$ or $s^{U E}$, whichever results in a higher lump-sum transfer. (iii) The cutoff level for university education with $s^{V E}$, denoted by $\widetilde{h}^{V E}$, satisfies $\widetilde{h}^{V E}>\widetilde{h}^{L F}$.

Proof. (i) If $h_{m}<v+c$ and subsidies are restricted to be below $s^{U E}=v-h_{m}+c$, the median voter chooses vocational education. Then $\widehat{e}=v$ and $\widehat{\tau}=\frac{1}{2 \delta}$ by Lemma $2 . s^{V E}$ is found by inserting these into (5) and maximizing with respect to $s$. (ii) By Proposition 3, $s^{U E}$ is optimal for those with vocational education if $s \geq v-h_{m}+c$. By the first part of this proposition, $s^{V E}$ denotes the optimal subsidy if this is restricted to be below $v-h_{m}+c$. As a result, the choice of the optimal subsidy without any other restriction than non-negativity boils down to choosing between these two. Depending on the distribution of $h$, either may prevail. (iii) In the Vocational Equilibrium, the required subsidy to reach $\widetilde{h}^{V E}=\widetilde{h}^{L F}$ would be $\frac{c}{2 \delta}$. The tax revenue from a citizen with $\widetilde{h}^{L F}$ would equal $\frac{1}{4 \delta}\left(\widetilde{h}^{L F}-v\right)=\frac{c}{4 \delta}$. Therefore, it is clearly optimal to lower the subsidy from the perspective of low-ability citizens. This would increase $b$ through two different channels. First, with given $\widehat{e}$ and $\widehat{\tau}$, it is not optimal that someone whose tax payment falls short of the cost of subsidy obtains university education. (The difference compared with Proposition 3 is that therein, subsidies allowed changing the educational choice of the median voter. This increased $\widehat{e}$ and reduced the required level of subsidy. Therein, cutting the subsidy even marginally would have cancelled the change in the identity of the median voter, causing a discrete downward jump in the investment in higher education.) Second, reducing the subsidy so that the previously marginal ability type no longer obtains education allows savings when also intramarginal ability types receive the same lower subsidies.

By Proposition 4, the optimal subsidy level can be associated with either inefficiently low investment in university education, with the median voter choosing vocational education, or in a larger fraction of population choosing university education than in a laissez-faire economy. In other words, subsidies are either so modest that the investment in higher education remains below its laissez-faire level and the majority of population chooses vocational education, or so generous that the majority of population obtains university education. Remember that by Proposition 2, there is no political support for subsidies among low-ability citizens, in case that the median voter would obtain university education also without subsidies.

This section proved that there can be scope for a unanimous agreement on introducing subsidies to university education. An alternative would be to assume voting in two stages. In the first period, there would be voting on subsidies to university education. In the second period, there would be voting on income redistribution. With such two-stage voting, the possibility of subsidies may render low-ability citizens worse off in the University Equilibrium 
than if there are no subsidies. The reason is that those who obtain university education could vote for high subsidies independently of any efficiency considerations, to pass part of the costs of their education to those who obtain vocational education. Clearly, the possibility of transferring income from low-ability minority obtaining vocational education to high-ability majority obtaining university education would widen the scope of ability distributions that could support the University Equilibrium.

\section{Discussion}

\section{The Role of Migration}

Towards the end of the 20th century, increased international competition has encouraged many countries to reduce tax rates on mobile factors of production. There are differing views on the welfare effects of increased mobility. Justman and Thisse (1997) have raised concern on inefficiently low public investment in higher education when the educated become mobile, and Poutvaara (2004) suggests that governments will educate too many students in countryspecific skills, and too few in internationally applicable fields. Wildasin (2000) concludes that mobility in itself reduces needs for public provision as it provides a market insurance for region-specific uncertainty. Andersson and Konrad (2003) argue that as the mobility of the highly educated reduces governments' scope for redistribution, it increases the private incentives for education. Thus, tax coordination even among benevolent governments may be undesirable, in line with what Kehoe (1989) concluded on taxing investments in physical capital. All these contributions suggest that public policies, either in a closed economy or with mobile labor, result in a risk of underinvestment in higher education.

This paper suggests that, in the presence of time-consistency problem, educating a larger fraction of cohort than in a laissez-faire economy may be optimal. By encouraging tax competition, globalization could undermine a social contract on subsidizing higher education. Indeed, an increasing number of European countries have increased the share of the costs of education that students must pay themselves, recently exemplified in the introduction of top-up fees in England.

One way to introduce mobility in the framework of this paper is to assume that the second period has three steps. In the first step, there is voting on taxes. In the second step, those with university education learn what would be their net income abroad. Some of them would have higher earning possibilities abroad, others at home. They then decide to stay or migrate. In the third step, production takes place, taxes are collected and transfers are paid. Migration would limit the incentives to tax high incomes, due to competition for the mobile tax base. The expected lower level of income redistribution in the second period would encourage choosing university education in the first period, reducing the need for subsidies.

\section{Complementarities in Production and Corporatist Labor Market}

This paper analyzed the case of linear production technology. Already Johnson (1984) and Creedy and Francois (1990) suggested that complementarities or positive externalities could motivate public subsidies to higher education. Likewise, if a corporatist labor market means that those with higher education earn less than their marginal productivity, this would be an additional motivation to subsidies. Galor and Moav (2006) even suggest that 
the demise of the capitalists-workers class structure resulted from the willingness of capitalists to support the provision of public education for the masses, in reaction to the increasing importance of human capital in sustaining their profit rates. Remarkably, none of these supplementary mechanisms was needed to derive the main results of this paper. Incorporating them in the presence of time-consistency problem when voting on redistribution is left for future research.

\section{Conclusion}

During the second half of the 20th century, income redistribution first increased dramatically and then levelled off in Western countries. This coincided with a significant expansion in the participation in higher education. In the 1980s and 1990s, the trend towards higher marginal tax rates was reversed and several countries started to reduce especially top marginal tax rates. This paper suggests that the increased capacity to redistribute income may have fuelled expansion in the higher education, due to time-consistency problem. The expansion of higher education, in turn, later helped to reduce income redistribution. The novel mechanism that this paper identifies is the following. By providing so generous subsidies to higher education that more than half of population chooses it, citizens give the median voter incentives to choose lower taxes in the future. Such a strategic expansion of higher education may be welcomed also by those who choose vocational education. It should be highlighted that even though this paper showed that subsidies to higher education may generate a Pareto improvement, the Pareto-improvement arises relative to income redistribution in the absence of subsidies. As the model assumed no market failures to motivate public intervention in the first place, the laissez-faire outcome is Pareto-efficient.

Towards the end of the 20th century, most OECD countries further scaled back especially top marginal tax rates, this time due to increased economic integration and mobility. By alleviating time-consistency problem, tax competition also reduces the strategic motivation to subsidize higher education that this paper highlighted. In Europe, the free mobility and increasing international mobility that the Bologna process is aimed to boost further suggest that while the 20th century saw an upward trend in both income redistribution and subsidies to higher education, the 21st century may witness a reduction in the tax burden on the highly educated and reallocation of the cost of financing higher education to students themselves. Furthermore, such a change may be associated with a reduction in the fraction of population obtaining higher education. A formal analysis of the dynamics associated with increased mobility, as well as studying the effects of population aging and technological change, are left for future research. 


\section{Appendix: Proof of Proposition 3.}

By Lemma 2, (6) and (7), both University Equilibrium and Vocational Equilibrium are subgame-perfect equilibria when $s=v-h_{m}+c$. By the assumption that the University Equilibrium is selected in case of multiple equilibria, $\widehat{e}=h_{m}$ and $\widehat{\tau}=\frac{1}{2 \delta}$. The lump-sum transfer in case of no subsidies is

$$
b^{n s}=\frac{1}{4 \delta} \int_{h_{i}=v+\frac{c}{1-\frac{1}{2 \delta}}}^{\bar{h}} f(h)(h-v) d h .
$$

The lump-sum transfer with subsidies is

$$
b^{s}=\frac{1}{4 \delta} \int_{h_{i}=h_{m}}^{\bar{h}} f(h)\left(h-h_{m}\right) d h-\left(v-h^{m}+c\right)\left(1-F\left(h_{m}\right)\right) .
$$

The citizens with $h<h_{m}$ gain from providing subsidies if and only if $b^{s}>b^{n s}$. This is equivalent to

$$
\frac{1}{4 \delta} \int_{h_{i}=h_{m}}^{\bar{h}} f(h)\left(h-h_{m}\right) d h-\left(v-h^{m}+c\right)\left(1-F\left(h_{m}\right)\right)>\frac{1}{4 \delta} \int_{h_{i}=v+\frac{c}{1-\frac{1}{2 \delta}}}^{\bar{h}} f(h)(h-v) d h .
$$

Rearranging and combining the terms gives (8).

Finally, notice that it is not optimal for those who choose vocational education to support any higher subsidies. If they would do so, those with $h<h_{m}$ who switch to university education would, in any case, avoid paying taxes as $\widehat{e}=h_{m}$.

\section{References}

[1] Andersson, F. and Konrad, K.A. (2003), Globalization and Risky Human-Capital Investment, International Tax and Public Finance 10, 211-228.

[2] Boadway, R., Marceau, N. and Marchand, M. (1996), Investment in Education and the Time Inconsistency of Redistributive Tax Policy, Economica 63, 171-189.

[3] Creedy, J., and Francois, P. (1990), Financing Higher Education and Majority Voting, Journal of Public Economics 43, 181-200.

[4] Galor, O. and Moav, O. (2006), Das Human-Kapital: A Theory of the Demise of the Class Structure, Review of Economic Studies 73, 85-117.

[5] Glazer, A. (1989), Politics and the Choice of Durability, American Economic Review $79,1207-1213$.

[6] Hassler, J., Rodríguez Mora, J.V., Storesletten, K. and Zilibotti, F. (2003), The Survival of the Welfare State, American Economic Review 93, 87-112. 
[7] Johnson, G. (1984), Subsidies for Higher Education, Journal of Labor Economics 2, 303-318.

[8] Justman, M., and Thisse, J.-F. (1997), Implications of the Mobility of Skilled Labor for Local Public Funding of Higher Education, Economics Letters 55, 409-412.

[9] Kehoe, P.J. (1989), Policy Cooperation among Benevolent Governments May Be Undesirable, Review of Economic Studies 56, 289-296.

[10] Konrad, K.A. (1995), Social Security and Strategic Inter-vivos Transfers of Social Capital, Journal of Population Economics 8, 315-326.

[11] Kydland, F. and Prescott, E.C. (1977), Rules Rather than Discretion: The Inconsistency of Optimal Plans, Journal of Political Economy 85, 473-491.

[12] Meltzer, A.H. and Richard, S.F. (1981), A Rational Theory of the Size of Government, Journal of Political Economy 89, 914-927.

[13] Poutvaara, P. (2004), Educating Europe: Should Public Education be Financed with Graduate Taxes or Income-Contingent Loans?, CESifo Economic Studies 50, 663-684.

[14] Schofer, E. and Meyer, J.W. (2005), The World-Wide Expansion of Higher Education in the Twentieth Century, American Sociological Review 70, 898-920.

[15] Shepsle, K.A. (1979), Institutional Arrangements and Equilibrium in Multidimensional Voting Models, American Journal of Political Science 23, 27-59.

[16] Tabellini, G. and Alesina, A. (1990), Voting on Budget Deficit, American Economic Review 80, 37-49.

[17] Wildasin, D.E. (2000), Labor Market Integration, Investment in Risky Human Capital, and Fiscal Competition, American Economic Review 90, 73-95. 